\title{
Application of Restorative Justice Against Crime Committed by Children in Polres Cirebon
}

\author{
Iwa Mashadi ${ }^{1}$ and Gunarto ${ }^{2}$
}

Abstract. Kids are an integral part of the survival expressly stated that the state guarantees the right of every child to survival, grow, and develop as well as protection from violence and discrimination. The protection of children is not only given to children who are victims of crime, but also to children who become perpetrators of criminal acts, so that the legal process especially in providing criminal decisions should also consider the future of the child as it is for a country, children are the hope of the future country. Towards children who commit criminal acts is also subject to criminal sanctions. Talking about the criminalization of children often contentious, because this issue has very broad consequences related to both self and community behavior. Punishment is an element of criminal law, in which the criminal prosecution has negative consequences for the given criminal sanctions. Along with Act No. 11 of 2012. While the effectiveness of sanctions against children in the perspective of restorative jusitce in Polres Cirebon Jurisdiction is quite effective because the victim, the offender and the community are satisfied with the settlement of Restorative justice and remembering the birth of Act No. 11 of 2012 Kids on the Criminal Justice System.

Keywords: Restorative justice, Crime Child.

\section{Introduction}

Child protection is part of the national development. Protecting children is to protect humans, and humans build as complete as possible. This is reflected in the nature of national development is to build a complete Indonesian man virtuous. Ignoring the child protection issues mean it will not strengthen the national development. Due to the lack of child protection will cause many social problems that can interfere with the enforcement of law, order, security, and national development. ${ }^{3}$

Crime in the community not only involving only adults but also in children under age. Children who originally still need a lot of guidance, instead it becomes the perpetrator of the crime. For example, an underage person who committed theft. So what then causes so that the child is doing theft ?. Of course there are many factors that lead to such. Then how is the juvenile criminal justice system response to events child as a criminal?

The concept of Restorative justice as stipulated in Act No. 11 of 2012 regarding the juvenile justice system to give space to the protection of and respect for and interests between the victim and the offender. The concept of Restorative justice puts the improvement of relations between the victim with the offender. With the concept is expected to provide justice for victims and perpetrators of criminal offenses

\footnotetext{
${ }^{1}$ Student of Master of Law, Universitas Islam Sultan Agung Semarang and Cirebon Police members email: maizakumpulanartikel03@gmail.com

2 Profesor of Faculty of Law UNISSULA Semarang

${ }^{3}$ Romli Atmasasmita 1997 Peradilan Anak Di Indonesia Bandung: Mandar Maju p. 166
} 
committed by children. Kids had been due to protection and guidance as it should be, but in reality there are many children are detained, punished, tried to put on trial.

The concept of Restorative justice is a concept in which the victim and the perpetrator are equally involved in the resolution of problems that cause kerguian for victims. Constructively so that this concept will bring to children who carry out criminal acts will be their fault, in other words the perpetrator will be aware that the criminal is not the obligation of retaliation. ${ }^{4}$

According Muladi, Restorative justice or Restorative justice is a theory that emphasizes recover damages caused or incurred by a criminal act. Restoring these losses will be achieved by the cooperative processes that include all stakeholders. ${ }^{5}$ The concept of Restorative justice is more focused on the creation of conditions of fairness and balance to the offender and the victim herself. Mechanisms procedure of criminal justice that focuses on the criminalization converted into a process of dialogue and mediation to create an agreement on the settlement of the criminal case that is more fair and equitable for the victim and the perpetrator. ${ }^{6}$

Implementation of Restorative justice aims at empowering victims, and encourage offenders to pay attention to the recovery. Restorative justice concerned the fulfillment of material needs, emotional and social victim. Measured by the success of Restorative justice for what has been restored offender, is not measured by how heavy sentence imposed judges. So whenever possible, the perpetrators were excluded from criminal proceedings and of prison. But as said Kent Roach, Restorative justice not only provide an alternative to prosecution and imprisonment, but also ask the responsibility of the offender. ${ }^{7}$

The approach used to achieve Restorative justice is to seek mediation between victim and offender, meetings and dialogue between victims and perpetrators of involving the family and the wider community, and raise awareness of the perpetrator and the victim. The main spirit of Restorative justice is not only to prosecute or punish the perpetrators but to repair and restore the victim and the perpetrator. Then the value of Restorative justice lies in the dialogue, understanding (mutuality), healing, repair, remorse and repentance, responsibility, honesty and sincerity. ${ }^{8}$

Restorative justice has expanded globally in the whole world. In many countries Restorative justice into one of a number of important approach to crime and justice are continuously considered in the judicial system and law. In accordance with the spread of this process all over the world then raised some of the innovations that are open to Restorative justice. As practiced in the United States, Canada, the UK, Belgium,

\footnotetext{
${ }^{4}$ Nurnaningsih Amriani "Penanganan Perkara Anak Melalui Konsep Diversi dan Restoratif Justice" Majalah Hukum Varia Peradilan Nomor 323 (Jakarta: IKAHI 2012) p. 72.

${ }^{5}$ Muladi 1995 Kapita Selekta Hukum Pidana Semarang: Universitas Diponegoro p. 125.

${ }^{6}$ Septa Candra Restoratif Justice: Suatu Tinjauan terhadap Pembaharuan Hukum Pidana di Indonesia "JurnalRechtsVindingMedia Pembinaan Hukum Nasional Vol. 2 No. 2 (Jakarta: Pusat Penelitian dan Pengembangan Sistem Hukum Nasional 2013 p. 264.

${ }^{7}$ Eriyantouw 2009 Wahid Keadilan Restoratif Justice dan Peradilan Konvensional Dalam Hukum Pidana Jakarta: Trisakti p. 4.

${ }^{8}$ S. Atalim Keadilan Restoratif sebagai Kritik Inheren terhadap Pengadilan Legal-Konvensional" Jurnal Rechts Vinding Media Pembinaan Hukum Nasional Vol. 2 No. 2 (Jakarta: Pusat Penelitian dan Pengembangan Sistem Hukum Nasional 2013) p. 145.
} 
the Netherlands and several other countries. Some countries are victims and perpetrators met in prison. ${ }^{9}$

In Restorative justice reckoned dignity of victims, and the perpetrators must be held accountable and be reintegrated into their communities. Perpetrators and victims domiciled balanced and interdependent, because it must be reconciled. Position the case of Restorative justice should be changed, no longer in the interests of order, but for the sake of victims and in terms of material and psychological recovery. So, to be realized in a Restorative justice the perpetrators of justice was to avoid imprisonment, and shall be responsible for his actions. ${ }^{10}$

This concept is in line with the approach restoratifjustice, for the purpose of diversion in accordance with Article 6 of the SPPA Law is:

- Achieving peace between the victim and children

- Resolving cases of children outside the judicial process

- Prevent children from deprivation of liberty

- Encouraging people to participate, and

- Instill a sense of responsibility to children.

Traditional Restorative justice is a concept that has been practiced in some countries, especially in parts of the East. This concept is believed to be an alternative in order to reduce unwanted excess as a result of the implementation of the formal criminal justice system. The conception has been running and applied in other countries and is believed to be an alternative to avoid the negative effects of the use of the formal system of judicial institutions sometimes produce something that is unwelfare in order to protect the legal interests of the parties. ${ }^{11}$

According to the UN, justice Restorative justice program is a program that uses restorative processes with the goal to achieve the desired results. The main purpose of the model is to restore peace and broken relationships through censure against the evil doer and strengthen the values that live in the community. the victims and the perpetrators need attention encouraged to take responsibility. ${ }^{12}$

Restorative justice appears triggered discontent over conventional Criminal Justice System and rooted in the practices of the natives. Restorative justice used against crime, discipline in schools and various other conflicts between citizens and government, the Commission Treaty of Waitangi in New Zealand ${ }^{13}$,

Restorative justice refers to the traditional ways, customs and religions related to the conflict, but the effectiveness of Restorative justice practices often rely on the criminal justice system is functioning properly and credible. Renewing emphasis on Restorative justice is often based on the view that the state is no longer regarded as the only source to achieve a fair and effective justice ${ }^{14}$, The concept of Restorative justice can also be seen as seeking new alternatives in resolving cases in reconciliatory involving victims, offenders, and the community. The concept of managed effectively resolve

\footnotetext{
${ }^{9}$ Marlina Op. Cit p. 196.

${ }^{10}$ Eriyantouw Wahid Op. Cit p. 2.

${ }^{11}$ Muhammad Ali Zaidan 2015 Menuju Pembaharuan Hukum Pidana Jakarta: Sinar Grafika 2015 p. 241.

${ }^{12}$ ibid. P. 241.

${ }^{13}$ Ibid. p. 242.

${ }^{14}$ Ibid. p. 248.
} 
cases classified mild start to the big cases such as murder. ${ }^{15}$

Legal protection for children can be interpreted as an effort to legal protection of the freedoms and rights of children (fundamental right andfreedom of child) as well as the various interests related to the welfare of children. Thus, the issue of legal protection for children include a very wide scope ${ }^{16}$ Children as the nation's next generation needs to be protected particularly from parents, the community and the government in order to realize a formidable and dignified generation. The child has a strategic role in the future development of the nation. Therefore, the government and the various instruments of law rules governing the protection of children with the aim of providing legal protection for children.

One of the legal protection granted by governments to children, especially children in conflict with the law is the enactment of Act No. 11 Of 2012 on Juvenile Justice System. In the context of all Acehan the enactment of Qanun No. 11 of 2008 on Child Protection, which regulates how the settlement of children in conflict with the law of child welfare approach through diversion. The preamble letter (d) of Act No. 11 of 2012 to formulate that Act No. 3 of 1997 on Juvenile Court is no longer appropriate to the development and needs of the community law because it has not comprehensively provide protection to children in conflict with the law and needs to be replaced with the enactment new legislation.

This indicates that the government's commitment to provide legal protection to children getting serious. The number of cases of children in conflict with the law who then ended up behind bars is an important concern. As a result, existing regulations that have not been able to accommodate the best interests of children and more likely to use formal pradilan eliminated by the enactment of Act No. 11 of 2012. The law put more emphasis on the concept of Restorative justice through diversion system. Even diversion efforts must be made at all levels of the law enforcement police, judiciary, and at the time of examination in the trial court.

Implementation through the juvenile justice system need to pay attention to the principles as set forth in Article 2 of Act No. 11 of 2012, namely: protection, fairness, non-discrimination, best interests of the child, respect for the views of the child, survival and child development, coaching and mentoring children, proportionately, deprivation of liberty and criminal prosecution as a last resort, and the avoidance of retaliation. $^{17}$

The criminal justice system and criminal punishment as a form of conflict resolution not to reply. Criminal and conviction of offenders is a form of accountability to the effect (impact) act of breaking the law and those who harmed directly as a result of the crime (victim) are active to resolve the conflict. Legal protection of victims during this time based on the Penal Code as substantive law, using the Criminal Code as the law of procedure. ${ }^{18}$

The criminal justice system is the embodiment of a series of criminal law enforcement authority composed of four sub-systems, namely:

\footnotetext{
${ }^{15}$ Ibid., p. 123.

${ }^{16}$ Waluyadi Op. Cit p. 1.

${ }^{17}$ Article 2 of Act No. 11 of 2012 on Child Criminal Justice System

${ }^{18}$ Siswanto Sunarso 2012 Victimologi dalam Sistem Peradilan Pidana cet. 1 Jakarta: Sinar Grafika p. 48
} 
- Powers of investigation (by the institution / body investigator)

- Prosecution powers (by weight / body prosecutor)

- Power to judge and pronounce sentence / punishment (by weight the Court)

- The enforcement authority / criminal (by agency / implementing agency / execution).

The law enforcement agencies have a relationship that can not be separated from one another and must be passed by stages respectively. An event that suspected criminal offenses must not be directly handled by the Prosecutor and the Court. But it must be done in advance by the police investigation. According Lilik Mulyadi, a dossier was declared complete results of the investigation formal and material completeness. The completeness of the dossier must contain the results of the investigation should include the following matters: ${ }^{19}$

- Complete identity of the suspect, as the provisions of Article 143 Paragraph (2) letter A Criminal Procedure Code.

- Permit chairman of the local District Court if conducted shakedown or confiscation (Article 33, Article 38 of the Criminal Code)

- Their special letter head of the local district court if the examination carried out letter (Article 47 of the Criminal Procedure Code)

- If the offense is to a complaint (kracht-delicten), there must be a letter of complaint from the person entitled;

- Investigator maid should have to meet certain requirements as provided in Article 2 paragraph (1), (2), Article 3 Paragraph (1), (2) government regulations.

- Manufacture Minutes shall comply with the provisions of Article 75 of the Criminal Procedure Code, if the examination of suspects, arrest, detention, seizure and so on and signed by the person entitled.

Completeness of the material so that the dossier meets the requirements transferred to the district court, among others, must comply with the evidence as provided for in Article 183, 184 Criminal Procedure Code as well as their descriptions carefully, clearly and completely the offenses alleged to mention about locusdelicti and tempusdelicti ( Article 143 Paragraph (2) b Criminal Code). Once declared complete case file (P-21), the Prosecution then made and the charges and transferred to the District Court which has jurisdiction to try the case ${ }^{20}$, After the prosecution filed the indictment, then the case can already be judged by a panel of judges who have been assigned by the President of the Court to hear and decide the case.

\section{Research methods}

The approach used in this study is a sociological juridical approach. Juridical and sociological approach is identify and conceptualize law sesbagai real social institutions and functional in a real life system. ${ }^{21}$ Sociological juridical approach is emphasizing research aimed at obtaining legal knowledge empirically by road directly involved keobyeknya is to know the legal protection against perpetrators of crimes committed under the age in Polres Cirebon.

\footnotetext{
${ }^{19}$ Lilik Mulyadi 2007 Hukum Acara Pidana Normatif Teoritis Praktik dan Permasalahannya Bandung: PT. Alumni p. 137-138.

${ }^{20}$ Ibid.p. 138.

${ }^{21}$ Soerjono Soekanto 1987 Pengantar Penelitian hukum Jakarta: UI Press 1987 p. 51
} 
Qualitative Research is a research aimed to describe and analyze the phenomena, events, social activities, attitudes, beliefs, perceptions, thoughts of people individually or in groups. Some descriptions are used to discover and explain the principles that lead to the inference. Qualitative research is inductive. Researcher let problems arise from the data or left open for interpetasi. Data collected by a detailed investigation, includes a detailed description of the context in which those records with the results of in-depth interviews, as well as the results of the analysis of documents and records. ${ }^{22}$ Qualitative research is penelititan which intends to understand the phenomenon of what is experienced by the subject of the study such behavior, perception, motivation, action. Qualitative research has two main objectives, the first of which, describe and reveal (to describe and explore) and both illustrate and explain (to describe and explaim). ${ }^{23}$

\section{Results and Discussion}

The criminal justice system (abbreviated as SPP) of children, which has been running as regulated in Act No. 3 of 1997 on Juvenile Justice and Act No. 8 of 1981 on the Criminal Code (Criminal Procedure Code), as a concept has been adequately protect children conflict with the law since the status of children becoming suspects and defendants in proceedings until court process, but often settling disputes through SPP's children can not defuse tensions between the victim and his family by the accused and their families. This is due to the practice of SPP often can not satisfy the parties.

SPP has been based on retributive justice only give the state authority delegated to law enforcement officers, authorizes the state delegated the police law enforcement officers, prosecutors, judges, and correctional institutions. Retributive justice by giving a reward for suffering or pain inflicted by the offender and therefore the perpetrators punished accordingly. State that determines the degree of justice for victims by giving prison sentences to perpetrators. Besides the judicial systemrelated criminal police, prosecution, courts, community organizations is an integrated system called the "criminal justice system", which was implemented in an effort to combat crime in the community, but the system is not yet fully implemented properly due to the fact that the crime rate is increasing and many culprits turned out to commit crimes or recidivists.

To overcome the weakness in the SPP that puts emphasis on retributive perpetrators and victims of crime passively. So with the advent of Restorative justice, restoration (recovery). Restorative justice looked at the first and earliest and directly harmed by the offender is an individual member of society, so that should they (the victim and the offender) was given a chance to resolve the conflict and restore the losses and allow the offender to carry direct responsibility for their actions, The aim of Restorative justice is to empower victims, perpetrators, families, and communities to

\footnotetext{
${ }^{22}$ Gempur Santoso 2005 Metodologi Penelitian Kuantitatif \& kuanlitatif Jakarta: Prestasi Pustaka Publisher 2005) p. 49

${ }^{23}$ Ibid.
} 
improve a tort by using awareness and conviction as a basis to improve people's lives. $^{24}$

Versioned as a new attempt regulated in Indonesian legislation, in addition to factors that support its implementation, there are also things that can hinder the implementation. A new one will be unfamiliar to those who have never listened to him, and never put it into practice. Especially for people who still feel not understand the concept of diversion. Because in general, parents will know when his term diversion against the law.

At the empirical level implementation, diversion of experiencing some of the following that may hamper the implementation, namely:

- Party Line Victim Wants Settlement Through Court

Settlement consists of two, litigation and non-litigation. Resolution of cases through the litigation settlement mechanism established in accordance with the criminal justice system, starting with the investigation at the level of the Police. Prosecutor-level judges at the examination at the trial. Parents of victims who do not want any diversion agreement at the level of the police, the case eventually forwarded to the court.

The tendency of the victim's parents prefer a solution through the formal justice mechanisms have several reasons: First, the victim's parents are prioritizing emotional in resolving cases of children. Most parents do not bear to see her treated and mistreated and beaten by other children. Retaliatory punishment became the primary choice in order to achieve satisfaction for him. Therefore, the victim's parents demanded that the perpetrators be resolved through the formal justice. $^{25}$

Second, Settlement through less traditional justice reflect justice. Moreover, who committed the crime came from the families who have positions. ${ }^{26}$

- Total Compensation Too Large

Failure diversion greatest effect is determined by a victim of an offense committed by children. Victims are basically a loss would consider giving forgiveness to the offender. Especially for criminal acts that cause harm as a result of persecution. The victim asked the offender and his family to account for the losses suffered. In cases that result in losses as a result of persecution, victims usually ask for some compensation, compensation for treating the entire loss.

Demand compensation is too high resulting in the failure of the diversion they do. As in the case of pembacokan that occurred in the Red Bridge Housing Arumsari Party some time ago. Victims appealed to the perpetrators of Rp 50,000,000.00, but could not be given by the family of the perpetrator. On completion in Polres Cirebon did not get the level of common ground through mediation. As a result, the process is pursued through the formal justice mechanisms. However, at the time of

\footnotetext{
${ }^{24}$ Dewi dan Fatahillah 2011 Mediasi Penal Penerapan Restorative Justice di Pengadilan Anak Indonesia Depok: Indie Publishing p. 4.

${ }^{25}$ Observation of diversion in the Police Sector Jaya Baru on Thursday 10 March 2018.

${ }^{26}$ Muhammad Nawawi interview on Tuesday January 262018.
} 
examination in court the case is successfully carried out a diversion to replace losses lighter. ${ }^{27}$

Cases were unsuccessful didiversi with too high a demand also occurred in the area of Polres Cirebon. The victim asked for 10 million to the perpetrators who numbered as many as three people. The offender is unable to meet the demands as requested by the victim's family, the case was unsuccessful diversion. As a result the case is pursued through formal mechanisms. ${ }^{28}$ Information obtained from the parents of other actors showed that the factors do not cause unsuccessful diversion due compensation is too high. ${ }^{29}$

Instead, the victim's family does not wish to explain that instead of peace with the players due to the amount of compensation. Compensation for himself does not really matter, because it involves affection to the children and families of the victims who came to the attitude of the family home to be unethical actors. Even according to him, to his family's arrival actors cursing by using harsh words. Therefore he did not give him forgiveness. ${ }^{30}$

Thus, the attitude of the parties in implementing the diversion determine the success or failure of diversion. Family offender who has the nature and ethics of good manners will melt the heart of the victim's parents. Instead, the victim's parents would not give forgiveness if the perpetrator's family did not show a good attitude to the parents of the perpetrators.

In addition, the professionalism of the officers involved was also one of the things that affect the success of diversion. Active involvement of the parties at the time of the diversion became one of the very attitudes that lead to successful diversion. Because at the time of diversion takes place, it takes a psychological approach to touch the hearts of the victims' families in order to forgive and be reconciled to his case. Through this approach, the peace between the family of the perpetrator and the victim's family can be realized. ${ }^{31}$

- Public understanding Still Less

The function of law in society is as a tool of socialengineering or as social engineering. To realize these goals socialization process of legislation becomes a necessity that should be pursued. This socialization process is important so that these laws can be used effectively in public life. ${ }^{32}$

Consequences that would arise if a legal product is not distributed to the public of each layer is a lack of public understanding of the substance of the rule. As a result, many people who do not understand and execute as stated in the statutory provisions. Act No. 11 of 2012 on Child Criminal Justice System as one example of a legal product that is not done effectively.

According Cut Ani, cases of children who are not successful at the level of Police due to diversion of public understanding is still lacking. Society considers that the

\footnotetext{
${ }^{27}$ Suhardi Sekdes Gampong Kuta Alam interview Monday January 252018.

${ }^{28}$ Afrizal interview Thursday March 102018.

${ }^{29}$ Rosmaida interview Thursday March 102018

${ }^{30}$ Observations at the time of the diversion in the Cirebon March 102018.

${ }^{31}$ Andi Lesmana Advocate interviews Tuesday January 262018

${ }^{32}$ Achmad Ali Wiwie Heryani 2012 Menjelajahi Kajian Empiris terhadap Hukum Jakarta: Kencana Prenada Media Group p. 144.
} 
child be punished with imprisonment. Whereas the obligation to implement diversion not only do the level of investigation done, but at the stage of prosecution and court diversion is still being done. Opportunities versioned implementation still to be done despite the diversion at the level of investigation and the Prosecutor failed. ${ }^{33}$

\section{Closing}

\subsection{Conclusion}

Application sanctions against children as a criminal in the perspective of Restorative justice in Jurisdiction Polres Cirebon applied in the form is returned to the parent / guardian in accordance with Article 11 and Article 71 paragraph (1) letter b number 3 of Act No. 11 of 2012, states that : Diversion agreement result can be:

- Peace with or without compensation;

- Handing it back to the parent / guardian;

- Participation in education or training at an educational institution or the Agency no later than 3 (three) months; or

- Society service.

\subsection{Suggestion}

To the description above conclusions, the authors make several suggestions, namely:

- The police can continue to promote the settlement of Restorative justice approach to criminal offenses committed by children and by conducting repressive efforts to prevent children from committing a crime.

- The role of parents in guiding children should be improved so that children do not commit a crime and are not exploited by certain parties to benefit.

\section{Bibliography}

[1] Achmad Ali and Wiwie Heryani 2012 Menjelajahi Kajian Empiris terhadap Hukum Jakarta: Kencana Prenada Media Group

[2] Dewi and Fatahillah 2011 Mediasi Penal Penerapan Restorative Justice di Pengadilan Anak Indonesia Depok: Indie Publishing

[3] Eriyantouw Wahid 2009 Keadilan Restoratif Justice dan Peradilan Konvensional Dalam Hukum Pidana Jakarta: Trisakti

[4] Gempur Santoso 2005 Metodologi Penelitian Kuantitatif \& kuanlitatif Jakarta: Prestasi Pustaka Publisher

[5] Lilik Mulyadi 2007 Hukum Acara Pidana Normatif Teoritis Praktik dan Permasalahannya Bandung: PT. Alumni

[6] Muhammad Ali Zaidan 2015 Menuju Pembaharuan Hukum Pidana Jakarta: Sinar Grafika

[7] Muladi 1995 Kapita Selekta Hukum Pidana Semarang: Universitas Diponegoro

\footnotetext{
${ }^{33}$ Cut Ani Director of LBH-Kids interviews Wednesday January 202018.
} 
[8] Nurnaningsih Amriani "Penanganan Perkara Anak Melalui Konsep Diversi dan RestoratifJustice" Majalah Hukum Varia Peradilan Nomor 323 Jakarta: IKAHI 2012

[9] Romli atmasasmita 1997 Peradilan Anak Di Indonesia Bandung: Mandar Maju

[10] S. Atalim Keadilan Restoratif sebagai Kritik Inheren terhadap Pengadilan LegalKonvensional" Jurnal Rechts Vinding Media Pembinaan Hukum Nasional Vol. 2 No. 2 Jakarta: Pusat Penelitian dan Pengembangan Sistem Hukum Nasional 2013

[11] Septa Candra Restoratif Justice: Suatu Tinjauan terhadap Pembaharuan Hukum Pidana di Indonesia "JurnalRechtsVindingMedia Pembinaan Hukum Nasional Vol. 2 No. 2 Jakarta: Pusat Penelitian dan Pengembangan Sistem Hukum Nasional $2013 \mathrm{hlm} .264$.

[12] Siswanto Sunarso 2012 Victimologi dalam Sistem Peradilan Pidana Jakarta: Sinar Grafika.

[13] Soerjono Soekanto 1987 Pengantar Penelitian hukum Jakarta: UI Press

[14] Act No. 11 Of 2012 on Child Criminal Justice System 